\title{
KUPA LÁSZLÓ (SZERK.): TÁJAK, TÁJEGYSÉGEK, ETNIKAI KISEBBSÉGEK KÖZÉP-EURÓPÁBAN
}

\author{
( $B$ \& D Stúdió, Pécs, 2007. 237 o.)
}

\section{KUGLER JÓZSEF}

A konferenciakötet a Magyar Szociológiai Társaság Nemzeti és Etnikai Kisebbségkutató Szakosztályának 2006. évi novemberi soros pécsi konferenciáján elhangzottakat adja közre. A köszöntőkön és egyéb mellékleteken túl több mint húsz elöadás anyagát ismerheti meg az olvasó.

A nagy természetföldrajzi-történeti táj, ahol élünk a Kárpát-medence, része egy még nagyobb fejlődéstörténeti nagytájnak, Közép-Európának vagy Kelet-KözépEurópának. E nagytérség elnevezése és határainak kijelölése talán még napjainkban is kissé bizonytalan. Mindenesetre az Elbától keletre fekvő területeket, a történelmi Csehországot, Ausztriát (osztrák tartományokat) a Kárpát-medencét (Magyar Királyságot az évszázadokig hozzátartozó Horvátországgal együtt), valamint a szerencsétlen sorsú egykori Lengyel Királyságot, a balti államokat és korábbi porosz fennhatóságú területeket foglalja magában. A nyugati (latin) kereszténység, a hozzákapcsolódó szellemi-ideológiai eszmeáramlatok, illetve társadalmi-politikai formációk a reneszánsz, a humanizmus, a reformáció-ellenreformáció, a felvilágosodás, a rendiség, az abszolutizmus stb. nemcsak a kontinens nyugati fele történeti múltjának meghatározó része, hanem térségünké is. Az időleges refeudalizáció, a polgári forradalmak korlátozott társdalom átalakító szerepe azonban már e nagytérség sajátossága épp úgy, mint a nyugat-európaihoz képest megkésett, és ezért attól eltérỏ fejlődési pálya. A klasszikus diplomácia elveire és hatalmi játszmáira építve a nagy uralkodócsaládok (a Habsburgok, a Hohenzollernek és a Romanovok) itt hozták létre soknemzetiségü birodalmaikat, amit leginkább a kisebbségi kérdés megoldatlansága, a háborús viszonyok közepette felerősödő nemzeti és a szociális mozgalmak romboltak szét a 20 . század elején. A 20 . század közepén pedig e térségben is érvẻnyesült a nagyhatalmi kiszolgáltatottság és a hidegháborús kettéosztottság. A kilencvenes évek elejének demokratizálódási folyamatát a legtöbb térségbeli állam esetében az uniós csatlakozás és integráció követte. A piacgazdaság kiépítése azonban a lakosságtól óriási áldozatokat követelt. E mellett az 1990-es évektől, több évtizednyi elfojtás után, újból kiéleződtek a nemzeti-nemzetiségi feszültségek is. A kultúra és a tudomány területén többek között Bécs, Budapest vagy Prága egyaránt jelentős alkotásokkal járult hozzá az egyetemes emberi értékek gazdagodásához. E változó világ egyes térségeiről, a megoldásra váró feladatokról, a kutatási eredményekröl ad ízelítőt a konferenciakötet. 
Az elmúlt évtizedekben, a gyorsan változó hatalmi-politikai viszonyok közepette a magyar tudományos élet képviselöi is számos nagyobb lélegzetủ munkát szenteltek a Kárpát-medencei és a tágabb közép-európai viszonyok bemutatásának, sokrétủ elemzésének. Elegendő csak Bulla Béla és Mendöl Tibor A Kárpát-medence földrajza c. könyvére vagy Rónai András Közép-Európa atlaszára gondolnunk. Kupa László éppen a konferencián ajánlott a hallgatóság figyelmébe egy már-már feledésre ítélt múvet, a Radisics Elemér szerkesztésében 1946-ban kiadott Dunatáj c. háromkötetes munkát, kiemelve a kötetek aktualitását, adatgazdagságát és sokrétűségét, vagyis a szerkesztö több tudományág (földrajz, történelem, diplomáciatörténet, közgazdaság) eredményeinek együttes bemutatására törekedett. A Duna összekötő szerepe fizikai és lelki-kulturális értelemben egyaránt évszázadok óta foglalkoztatja a kontinens egységének megteremtését célul tűző gondolkodókat, politikusokat. Éppen napjainkra valósulhat meg tehát ez a sok évszázados álom, mivel a horvátországi és szerbiai folyószakasz, illetve a deltavidék egyes részeinek kivételével már akár belső uniós folyóként is értelmezhetô a Duna.

A kötetben közreadott előadások négy témakörhöz kapcsolódnak: $A$ táj, régió, határmentiség elméleti kérdései, illetve az e témakörhöz tartozó néhány kutatási eredmény közzététele képezi az elsöt. Kocsis Károly a Kárpát-medencei tájfelosztás eddigi föbb eredményeit foglalta össze a honi geográfiai szakirodalom alapján, míg Hajdú Zoltán a térség etnikai tájainak történeti és politikai földrajzi problematikájáról adott összegző áttekintést, kiemelve egyebek mellett az államhatárok gyors és radikális megváltoztatásának máig ható következményeit is. A jelenröl és a formálódó jövöröl, a kelet-közép-európai régiók fejlődési pályájának alakulásáról tartott előadást Horváth Gyula, aki igyekezett eloszlatni azt a napjainkban szélesebb körben elterjedt tévhitet is, miszerint az uniós pénzek mindent megoldhatnak. A pécsi professzor egyebek mellett kiemelte: „Azok a régiók, amelyek kizárólag az Európai Unió támogatáspolitikájától várták boldogulásukat, és az éppen aktuális fejlesztéspolitikai célok megvalósítására törekedtek, nem voltak képesek relatív pozíciójukon javítani” (43. o.). Nagy-Zekmi Sylvia a határtérség és identitás elméleti megközelítésére vállalkozott angol nyelvủ tanulmányában. Bali Lóránt pedig a Kárpát-medencei határ menti kutatások ủjabb eredményeire, Baranyi Béla A határmentiség dimenziói (Magyarország és keleti államhatárai) címủ könyvére hívta fel a jelenlévök figyelmét.

Az asszimiláció, az együttélés és a kisebbségi lét egy-egy szeletének bemutatását célul tũzõ tanulmányok alkotják a második témakört. Majdán János a vasút és a különböző ajkú magyar állampolgárokból verbuválódó vasutasság dualizmuskori asszimilációs és modernizációs szerepét mutatta be, míg Nagy Mariann ugyanezen idöszak magyarországi nemzetiségi régiói agrártársadalmának sajátosságait vázolta. Lénárt Imre szociológiai felmérése azt vizsgálta, hogy a Kárpát-medencei magyarság közel egy évszázados, országhatárok általi megosztottsága hatással van-e a fiatalok mindennapi viselkedéskultúrájára. A Duna-Körös-Maros-Tisza Eurorégióban élő magyar kisebbség néhány népességföldrajzi sajátosságát Pál Ágnes összegezte. 
Tér és Társadalom 23. évf. 2009/1. 219-238. p.

Egy-egy Kárpảt-medencei kistérség országrész (ország) sajátos kisebbségi problémáinak feltárását elvégzö tanulmányok képezik a kötet legszámottevóbb csoportját. Több szerző foglakozott a Kárpát-medencei délszláv kisebbségek valamelyikével, akik, mint közismert, több mint ezer éve élnek a magyarság környezetében, a törökellenes háborúk időszakát követően pedig számos délszláv szórvány jött létre föként a magyar nyelvterületbe ékelődve. Az észak-bácskai bunyevác-, a rác- és a sokáchorvátok származási és letelepedési helyeiről Gorjánácz Zsivkó adott áttekintést. Barics Ernő a Dráva menti horvátok két világháború közötti nyelvi asszimilációját, illetve e folyamatban az oktatás és a pedagógusok szerepét vizsgálta. A Mura menti (Zala megyei) horvát falvakban végzett kutatásairól Kanizsai Mária számolt be, aki többek között megállapította: „Identitástudatukat a szükebb pátriához, a Mura menti kajhorvát etnikumhoz és a magyar államhoz való állampolgári tartozás tudata jellemzi." (145. o.) Az elmúlt évtizedekben a belföldi turisták által egyre kedveltebb Vendvidék falvainak etnikai és társadalmi-gazdasági viszonyit pedig Mohos Mária elemezte. A honi németség körében elért kutatási eredményeit is több elöadó osztotta meg a hallgatósággal. Ez azért sem meglepö, mivel a trianoni országterület német kisebbségi településeinek jelentős része éppen a Dél-Dunántúlon található. Gerner Zsuzsanna A magyarországi német nyelvi szigeteken bekövetkezett nyelvváltás objektiv és szubjektív okait tárta fel. Bindorffer Györgyi ezúttal négy német lakta település (Dunabogdány, Bánd, Csolnok és Nagynyárád) helyi nyelvhasználati gyakorlatát hasonlította össze. Egy Magyarországon még viszonylag újszerünek tünö témát boncolgatott elöadásában Hammer Erika, aki a tér filozófiai-irodalmi megközelítését elemezte a kultúrák találkozásának szemszögéből. Baranyai Gábor és Tóth József tanulmánya a Baranya megyei német és horvát kisebbségi oktatásról adott összefoglalót.

A konferencián természetesen nem maradhattak el a Kárpát-medencei magyarság sorskérdéseivel foglalkozó elöadások sem. A határon túli magyar felsőoktatási intézményeket és kisebbségi intézeteket Molnár Margit vette számba, míg Bálint Lajos a trianoni országterület régióinak mortalitási mutatóiról készitett összegzést. A kényszerüségből kisebbségivé vált magyarok közül már csak a határ közelsége és az erősödő pécsi kapcsolatok miatt is, a délvidéki (vajdasági) kutatási eredmények közzététele dominált. Arra a kérdésre, hogy Trianon után a délvidéki magyarság milyen helyet foglalt el a korabeli magyar külpolitika alakításában Hornyák Arpád keresett választ. A délvidéki magyarság történelmi tudatának sok évtizedes változásáról Ózer Ágnes tartott előadást, megállapítva egyebek mellett azt is: „A közös történelmi sors és a történelem akaratunktól függetlenül is, nemcsak a vajdasági magyarság kisebbségbeli történelmét, hanem az egyetemes magyar történelmet is beépítette a modern Vajdaság multietnikus társadalmi modelljének alapjaiba." (108-109. o.) Ugyancsak a vajdasági magyarság körében végzett statisztikai-szociológiai vizsgálatairól számolt be Gábrity Molnár Irén. A szabadkai professzorasszony hangsúlyozta, hogy a vajdasági magyarok közelmúltban bekövetkezett viszonylagos lemaradása iskolai végzettségüket illetöen leginkább esélyegyenlötlenségük miatt következett be. 
Jelen konferenciakötet tehát bátran ajảnlható a teret kutató szakembereknek, a regionális tudomány múvelöinek is. Szűkebb-tágabb környezetünkről, a Kárpátmedencéról, pontosabban annak egyes térségeiről ugyanis számos hasznos információt meríthetünk az elhangzott előadásokból. A tájak, tájegységek, kistérségek, régiók múltjának és jelenének alapos ismerete is hozzájárulhat ahhoz, hogy a jövöt építö fejlesztési koncepciók vagy éppen a határ menti együttmúködést segitő fejlesztési programok minél eredményesebbek és tartalmasabbak legyenek. 